\title{
Marketing planning and digital customer loyalty data in small business
}

\author{
Christina Donnelly \\ School of Business, NUI Maynooth, Maynooth, Ireland \\ Geoff Simmons and Gillian Armstrong \\ Ulster Business School, University of Ulster, Newtownabbey, UK, and \\ Andrew Fearne \\ Kent Business School, University of Kent, Canterbury, UK
}

\section{Digital customer loyalty data}

515

Received 24 August 2011

Revised 15 March 2012

Accepted 29 March 2012

\begin{abstract}
Purpose - Retailer loyalty card marketing intelligence presents actual customer purchasing preferences, competitor activities and performance. Typically, extant literature implies that larger firms with formal marketing planning approaches will be more able to leverage it, structured as it is within a formalized statistical format. Small business literature on the other hand emphasizes their more informal approach to marketing planning. The purpose of this paper is to consider, for the first time, the potential relationship between retailer loyalty card marketing intelligence and small business market orientation.

Design/methodology/approach - A conceptual model is developed which diagrammatically interprets how retailer loyalty card marketing intelligence can relate to small business market orientation. Propositions provide a basis for further discussion with applied and research implications. Findings - A pertinent aspect of the conceptualization is the role of small business owner-manager insight and intuition within an experiential learning context. A complementary relationship is posited in the leveraging of retailer loyalty card marketing intelligence to enhance small business market orientation, which with higher levels of entrepreneurship orientation can lead to positive organizational outcomes, such as facilitating more successful and informed engagement with larger suppliers.

Originality/value - The paper addresses the increasing pressure small businesses face in dealing with retailer loyalty card marketing intelligence. Generally, literature has yet to adequately address marketing planning implications for firms. The informal/formal tension when considering small businesses presents a particularly interesting area of conceptual development, integrating market orientation literature and also recent developments which point to interaction between market and entrepreneurship orientations. This paper therefore provides a basis for a new small business research agenda in an area which is highly topical and important, with a synthesis of the extant literature in developing a conceptualization and propositions. The conceptualization and propositions can facilitate the development of new research and thinking in this potentially fruitful area of future enquiry.

Keywords Small enterprises, Marketing management, Marketing planning, Marketing intelligence, Market orientation, Entrepreneurship orientation, Small business marketing, Retailer loyalty card

Paper type Conceptual paper
\end{abstract}

\section{Introduction}

Marketing planning is recognized as vital for small businesses, creating an interface with the external environment in which they operate (Zontanos and Anderson, 2004). Small businesses which strive for market development, and which continuously search for new market opportunities and expansion of the consumer base, have a better chance of survival and growth (Baker and Sinkula, 2009). It is the unique nature of small businesses that shapes and dictates the manner in which their marketing is

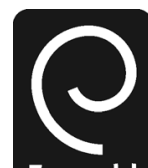

Emerald

Marketing Intelligence \& Planning Vol. 30 No. 5,2012 pp. $515-534$

(C) Emerald Group Publishing Limited 0263-4503

DOI $10.1108 / 02634501211251034$ 
MIP

30,5

516 performed (Nieto and Santamaria, 2010). Their smaller size is a significant factor influencing marketing planning processes (Gilmore et al., 2001, 2006; O’Dwyer et al., 2009). Their size gives them relatively little impact in terms of modifying their environmental surroundings and makes them dependent on a small consumer base (Jones et al., 2007). However, their smaller size allows them to form closer relationships with customers, providing flexibility in operations and responsiveness to change (Moriarty et al., 2008).

Small businesses can overcome the typical advantages of larger firms, such as market power and economies of scale, by being market-oriented (Alpkan et al., 2007). Narver and Slater (1990, p. 21; see also Kohli and Jaworski, 1990) define market orientation (MO) as "the organization culture that most effectively and efficiently creates the necessary behaviors for the creation of superior value for buyers and, thus continuous superior performance for the business." While a substantial academic literature has examined MO, this work is theoretically limited with respect to the characteristics of small businesses (Blankson et al., 2006). MO for small businesses is not determined by formalized and complex planning processes organized around the generation, dissemination of, and response to marketing intelligence, as in larger organizations (Kohli and Jaworski, 1990). Small businesses strive to compete in global markets through MO that is built on their owner-managers' insights, preferring pragmatic and intuitive generation, dissemination of, and response to marketing intelligence (Moriarty et al., 2008). The small business literature emphasizes the focal role of owner-managers to the nature and level of business conducted (Hult et al., 2003; Wilson and Stokes, 2004; Zontanos and Anderson, 2004). The owner-manager will be running the business, or be responsible to a large extent for its failure or success which can be critical to them achieving personal and business goals (Mazzarol et al., 2009).

Armario et al. (2008) state that MO facilitates the development of small business learning processes, as owner-managers apply their knowledge to the solution of market problems. These learning processes relate to the unique nature of small businesses (e.g. limited resource base, simple organizational structure, informal business processes, networking, owner-manager dominance - Blankson and Omar, 2002; McCarton-Quinn and Carson, 2003; Moriarty et al., 2008). Larger firms have the resources to develop learning-based $\mathrm{MO}$ routines centered on marketing intelligence, in a planned and structured manner, which is beyond the means of most small businesses. An empirical study by Blankson et al. (2006), found that owner-manager learning capabilities were based upon a more informal, unstructured and experiential context when engaging with marketing intelligence.

Marketing intelligence underpinning MO is being transformed by the increasing availability of new sources such as retailer loyalty cards. Small businesses are being significantly impacted by the increasing competitive pressure exerted by the availability of retailer loyalty card marketing intelligence (Mauri, 2003; Dunn, 2006; Cacciolatti et al., 2009). Larger businesses are actively purchasing it as an invaluable form of formalized marketing intelligence which presents actual customer purchasing preferences, competitor market activities and performance. The term formalized signifies that the marketing intelligence is structured within a statistical format, with tables, graphs and charts illustrating market growth, trends and profiles (Anstead et al., 2008). Smaller businesses do not have the resources, financially or in terms of expertise, to acquire and leverage it putting them at a competitive disadvantage (Cacciolatti et al., 2009). However, as multiple retailers open up their shelves to small (local, niche) suppliers to differentiate their retail offer, they are making efforts to 
remove the barriers for this part of their supply base. Subsequently, there are increasing moves to make access to and provide interpretive support for small businesses. This makes it particularly pertinent to the small business marketing planning literature, and indeed to the wider small business management literature.

It can be broadly argued that larger firms will be more suited to adopting retailer loyalty card marketing intelligence, with their more formalized and structured marketing planning approach to generating, disseminating and responding to marketing intelligence. Small business literature on the other hand emphasizes a more informal and intuitive approach. However, recent work by Simmons et al. (2011) would suggest that formalized marketing intelligence may potentially complement and support the more informal type of marketing planning small businesses' practice. Drawing on these issues in this paper we consider for the first time the potential relationship between retailer loyalty card marketing intelligence and small business marketing planning represented by the MO concept. Generally, literature on retailer loyalty card marketing intelligence has yet to adequately address marketing planning implications for firms. The informal/formal tension which is introduced by the small business context is a particularly interesting area of study in this respect.

The fundamental premise in this paper, in setting a new small business research agenda, is that the relationship between retailer loyalty card marketing intelligence and small business MO could be transformative. That is, while formalized and therefore potentially foreign to the informal nature of small business MO, retailer loyalty card marketing intelligence may complement it. Consistent with this premise, and after reviewing existing treatments of MO, small business MO and retailer loyalty card marketing intelligence in the literature, we synthesize this literature to develop the conceptualization that interprets the relationship between small business MO and retailer loyalty card marketing intelligence. Although this paper is not empirically based, the conceptualization and propositions developed from this premise will facilitate the development of new research and thinking in this potentially fruitful area of future enquiry. Acknowledging recent developments in the small business literature on interaction between $\mathrm{MO}$ and an entrepreneurship orientation (EO) (Baker and Sinkula, 2009), we also integrate into the conceptualization the potential relevance of EO to the relationship.

Studies to date have addressed the history and development of retailer loyalty cards, by considering the technology involved in collecting and extracting marketing intelligence and the impact of the loyalty schemes in relation to the shopper and the retailer (Ziliani and Bellini, 2004). Actual understanding of how the data can be used for marketing planning is not clear. The focus has been placed on the potential of the loyalty card increasing customer loyalty, rather than the loyalty card providing a source of marketing intelligence that can be used in marketing planning (Cortiñas et al., 2008). In this paper we explicate marketing planning implications for small business owner-managers in accessing and utilizing retailer loyalty card marketing intelligence. Multiple retailers are increasingly making this marketing intelligence available to smaller firms, often supported by relevant government agencies. What we attempt to emphasize is that small business owner-managers should not fear or have apprehension when considering retailer loyalty cards as a source of marketing intelligence to inform their marketing planning. Rather, they need to realize that to compete with larger firms that have intelligence access and interpretation skills, and to gain acceptance for their products and services on multiple retailer shelves, there may be significant benefits for them in engaging with retailer loyalty card marketing intelligence. If this

\section{Digital customer loyalty data}


MIP

30,5

518 understanding is created, this could have potential significance for the small businesses marketing going forward.

Key to this is creating an understanding of how new forms of formalized marketing intelligence such as retailer loyalty cards, can be integrated into the marketing planning process for small businesses. If, as proposed in this paper, the introduction of retailer loyalty card marketing intelligence can raise the level of small business owner-manager $\mathrm{MO}$, then our understanding of this and the relationship with informal aspects of small businesses marketing planning appear critical. Owner-manager insight is posited to be key to this, facilitated by their intuition underpinning marketing planning approaches. We consider the relationship between formalized retailer loyalty card marketing intelligence and informal owner-manager insight and intuition in the context of experiential learning. The role of EO is presented as integral to this. A complementary alignment of an enhanced MO through exposure to retailer loyalty card marketing intelligence, and with high levels of EO, can facilitate small business owner-managers in marketing planning that can proactively exploit market opportunities. These contributions also facilitate new insights into how retailer loyalty card marketing intelligence can have relevance to marketing planning in small businesses particularly. Understanding of retailer loyalty cards and their relationship with marketing planning to this point has not been developed (Cortiñas et al., 2008).

We now proceed by developing relevant literature. From this literature and its theoretical synthesis a conceptualization is developed. Applied implications are then explicated before conclusions and directions for further research are presented.

\section{Theoretical background}

\section{$M O$}

MO is essentially the application of the concept of marketing, which implies that the basic function of the firm is to generate new customers (Drucker, 1954). It is based upon marketing intelligence, its generation, dissemination and an organization's response to it (Kohli and Jaworski, 1990: Jaworski et al., 2000), as well as the culture that most effectively creates and nurtures these behaviors within a customer and competitor orientation (Narver and Slater, 1990; Narver et al., 2004). The value of MO to this paper is therefore significant, as it underpins our conceptualization of the relationship between small businesses and retailer loyalty card marketing intelligence. It is therefore also integral to small business marketing planning, whether formally or informally defined around retailer loyalty card marketing intelligence. Various authors have provided definitions of MO over the past 20 years or so.

Table I provides the reader with a comprehensive overview of MO definitions.

As a theory MO began to develop in the 1990s, with discussion about the construct and its nature and consequences for firms (Kerin, 1996). Since then, research has intensified seeking to measure its effects on firm performance, as well as its influence on internal marketing planning initiatives. In terms of conceptual development, MO is behaviorally based upon the generation of marketing intelligence relating to the needs of current and future customers, the dissemination of this intelligence throughout the firm, and the strategic market response (Kohli and Jaworski, 1990). In other words, it implies acquiring information from buyers and competitors in the target market and disseminating this information throughout the company. Integral to this, MO also implies having the cultural values and norms, to enable the acquisition of information from buyers and competitors in the target market, and its dissemination throughout the company (Narver and Slater, 1990). 
Shapiro (1988, pp. 120-2)

Kohli and Jaworski

(1990, p. 6)

Narver and Slater

(1990, pp. 20-1)

Jaworski and Kohli

(1993, p. 467)

Deshpande and Farley

(1998, p. 467)

Day (1994, p. 37)

Hunt and Morgan

(1995, p. 11)

(Jaworski and Kohli, 1996, p. 131)

Deshpande and Farley (1998, p. 226)

Harris (2002, p. 247)
"Information on all important buying influences permeates every corporate function." "Strategic and tactical decisions are made interfunctionally and interdivisionally" and "divisions and functions make well-coordinated decisions and execute them with a sense of commitment"

"Organisation-wide generation of market intelligence pertaining to current and future customer needs, dissemination of the intelligence across departments, and organisation-wide responsiveness to it" "The culture that most effectively and efficiently creates the behaviours for the creation of superior value for buyers," state that MO "consists of three behavioural components - customer orientation, competitor orientation, and interfunctional coordination - and two decision criteria - long-term focus and profitability"

"Organisation-wide generation of market intelligence pertaining to current and future customer needs, dissemination of the intelligence horizontally and vertically within the organisation, and organisation-wide action or responsiveness to market intelligence" "A set of beliefs that puts the customer's interest first, while not excluding those of all other stakeholders such as owners, managers, and employees, in order to develop a long-term profitable enterprise" "superior skills in understanding and satisfying customers"

"The systematic gathering of information on customers and competitors, both present and potential, the systematic analysis of the information for the purpose of developing market knowledge, and the systematic use of such knowledge to guide strategy recognition, understanding, creation, selection, implementation and modification" "Organisation-wide generation of market intelligence pertaining to customers, competitors, and forces affecting them, internal dissemination of the intelligence, and reactive as well as proactive responsiveness to the intelligence"

"A set of behaviours and processes related to continuous assessment and serving customer needs"

"The extent to which an organisation is perceived to act in a coordinated, customer and competitor-orientated fashion"

\section{Digital customer loyalty data}

519

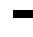

Table I.

Definitions of market orientation

These approaches according to Cambra-Fierro et al. (2011, p. 446) should be considered as overlapping, where MO is "a cultural orientation with behavioural implications." To disassociate these two MO perspectives would lead to what Avlonitis and Gounaris (1997, p. 38) term “an erroneous viewpoint.” Homburg and Pflesser (2000) reconciled the contemporary definitions established by Narver and Slater (1990) and Kohli and Jaworski (1990), with the culture of MO preceding behaviors characterizing a marketorientated organization. More recently, Narver et al. (2004) define MO on a continuum with reactive (responding to expressed customer needs and representing extant thinking on $\mathrm{MO}$ ) at one side and proactive (responding to latent customer needs) at the other. Their theoretical expectation is that by introducing the concept of a proactive $\mathrm{MO}$, there will be a significant contribution to the explanatory power of a responsive MO. The presence of a strong MO facilitates improved business results, whether in the context of large firms (Slater and Narver, 1994; Jaworski and Kohli, 1993; Panigyrakis and Theodoridis, 2007; Menguc and Auh, 2006), or in small businesses (Pelham, 2000; Martin et al., 2009). As well, market-oriented enterprises assume that their customers' needs change, and that adapting to changing market forces can generate opportunities for growth and profits (Martin et al., 2009). 
MIP

30,5

520
The behavioral process associated with MO is integrally linked with adaptive learning (Baker and Sinkula, 1999; Slater and Narver, 1995). Single-loop (Argyris, 1977), or adaptive (Senge, 1990), learning supports tactical adjustments to marketing planning and implementation (Sinkula, 1994; Sinkula et al., 1997). Market-driven behavior develops from adaptive learning and provides a basis for creating competitive advantage (Kohli and Jaworski, 1990; Narver and Slater, 1990; Jaworski and Kohli, 1993; Day, 1994). It can enable firms to develop incremental innovations through a focus on expressed customer needs. Incremental innovations represent ongoing improvements to existing product, marketing planning processes and service (Han et al., 1998; Slater and Narver, 1999). However, an MO is not intrinsically capable of facilitating radical innovation (Baker and Sinkula, 1999; Slater and Narver, 1995). Indeed, $\mathrm{MO}$ has been criticized for overlooking competition from non-traditional sources and focussing more on current customers' expressed needs and less on future customers' latent needs. It is consideration of these latent needs that creates the potential for radical innovations that represent advancements in knowledge and the consequent development of radically new products and marketing planning processes to open up new market spaces (Chandy et al., 2003; Gatignon and Xuereb, 1997; Hamel and Prahalad, 1994).

\section{Small business $M O$}

In small business literature a common theme is the issue of resource constraints relating to time, expertise, finance or labor, for example. Overcoming resource constraints, competitive advantage is leveraged from the speed with which they can respond to customers' wants and needs with their marketing planning processes (Li et al., 2008). In so doing, their capacity for adjustment depends on this flexibility and responsiveness (e.g. limited resource base, simple organizational structure, informal business processes, networking, owner-manager dominance - Blankson and Omar, 2002; McCarton-Quinn and Carson, 2003; Moriarty et al., 2008; Baker and Sinkula, 2009; Nieto and Santamaria, 2010).

Despite the attention given to MO by researchers more generally, small-businessspecific research has been limited (Blankson et al., 2006). To appreciate, understand and practice $\mathrm{MO}$ is a challenge for many small businesses (Pelham and Wilson, 1996; Harris and Watkins, 1998; Blankson and Stokes, 2002; Blankson et al., 2006). Notwithstanding, Kara et al. (2005) found that MO can be positively correlated to small business performance. This is further supported through studies by Pelham (1997) and Harris and Watkins (1998). However, factors may exist which restrict or prohibit small businesses from developing their MO. In a study of small hotel businesses, Harris and Watkins (1998) found that several factors impeded their ability to fully appreciate, understand and develop an MO. These include ignorance of the concept and its application, limited resources, perceived inappropriateness, contentment with status quo, short-termism in their marketing planning, unclear views of the customer and finally a lack of competitive differentiation.

The small business literature overall, indicates that small and larger businesses have different characteristics and therefore should be studied separately. This is a significant literature stream for this paper as it provides a basis for understanding the daily operations of the small business. Indeed, Welsh and White (1981) first introduced the now popularized notion that a small business is not a little big business, and this is still being emphasized in the literature today (Renko et al., 2009). Where small business MO differs from larger businesses, is in a literature focus on their informality 
integrated with a view that they are defined very much by the personal commitment and characteristics of their owner-managers. Owner-manager influence creates an individual, informal and often idiosyncratic approach to the way small businesses are managed (Perks, 2006; Jones et al., 2007). Small business MO is therefore fundamentally characterized by the management style and personality of their owner-managers (Moriarty et al., 2008; Simmons et al., 2008).

Owner-manager perceptions of marketing have in many cases emerged from the belief that they can successfully achieve sales without formally planning their marketing activities (Stokes, 2000). Planning in small businesses is largely viewed as informal and largely resident in the head of, and dependent upon, owner-managers (Miller and Toulouse, 1986; McCarthy, 2003). Owner-managers prefer pragmatic action in the immediate time-frame depending on speed and agility to respond to customers (Li et al., 2008), rather than formalized planning and the contemplation of future desirables (Kirchoff, 1994; Doern, 2009). Other scholars have found that ownermanagers are rarely planners who focus on the long term or act according to rational principles; instead they act on insights, intuition and impulse (Bhide, 1994).

Owner-managers are therefore focussed more on the "here and now" in marketing planning, intuitively assessing short-term achievements and learning experientially by doing (derived from the accumulated knowledge of doing business: Clarke et al., 2006) as opposed to thinking ahead and developing longer-term marketing objectives due to time, expertise and resource constraints (Armario et al., 2008; Blankson et al., 2006; Clarke et al., 2006; Lewis et al., 2007; O’Dwyer et al., 2009; Liberman-Yaconi et al., 2010). This differs from the formalized forward marketing planning favored by senior managers in larger firms. It also presents potential difficulties when one considers the relationship between small business MO and the formalized nature of retailer loyalty card marketing intelligence. Notwithstanding, larger firms are proactively leveraging retailer loyalty card marketing intelligence which presents a competitive challenge to small firms. The next section develops this further.

\section{Retailer loyalty cards}

Consumers have been the focus of much MO literature to date, being regarded as pivotal to all definitions. Jones and Rowley (2011, p. 28) emphasized the importance of "developing an attitude of consistent consumer dedication." Yet a narrow focus on consumers can lead to an unbalanced outlook by firms, with the need for a competitor focus also apparent in the literature (Sorensen, 2009). Competitor orientation ensures that firms understand their short-term strengths and weaknesses by acknowledging the long-term capabilities and marketing planning of both the main current and main potential competitors (Narver and Slater, 1990). Lafferty and Hult (2001), however, suggest that a competitor orientation is similar to that of consumer orientation as it requires information gathering to occur. Essentially it is argued that different types of information can be gleaned through a focus on consumer orientation or competitor orientation. This information can be used depending on the type of decision to be made or the type of decision maker. Therefore a firm's use of competitor information is a vital piece of input in the marketing planning process, particularly when the market is led by businesses which ultimately drive the industry.

The source of consumer and competitor information has in recent years being significantly influenced by new database technologies. A key feature of this has been the emergence of large data warehouses that can store consumer and competitor data on a scale hitherto unheard of or achievable. These warehouses have been critical to the

\section{Digital customer loyalty data}

521 
MIP

30,5

522 growth and dominance of multiple retailers from Walmart in the USA to Tesco in the UK. Power for multiple retailers resides in their proximity to end consumers and their ability to extract significant quantities of consumer data. In the UK, for example, Tesco have the largest consumer base considered representative of the UK population as a whole (Anstead et al., 2008). Marketing intelligence is increasingly orientated around retailer loyalty cards which are intrinsically linked to large data warehouses. This marketing intelligence can be interpreted by market research agencies such as dunnhumby (who manage Tesco Clubcard data) to provide information and marketing intelligence that goes beyond that gathered by more traditional market research surveys, for example. According to Dunn (2006, p. 47) "you need to look at real (consumer) behaviour, real motivation, and you need to be able to link all that knowledge."

Loyalty cards are a relatively new phenomenon presenting opportunities for further academic research and understanding. Most studies to date have focussed on loyalty cards from the consumer's perspective, in terms of exploring the link with loyalty (Wright and Sparks, 1999; Turner and Wilson, 2006; Everett, 2009; Smith and Sparks, 2009). Significant gaps exist in the literature in respect of the formalized marketing intelligence derived from retailer loyalty cards and the impact in terms of marketing planning. In particular, Cortiñas et al. $(2008$, p. 52) point to the need for further exploration of retailer loyalty card marketing intelligence for marketing planning purposes: "the main potential of loyalty cards may lie not so much in increasing consumer loyalty as in providing a source of useful data on consumer behaviour that can later be used to design better adjusted marketing strategies."

Access to and the ability to analyze this form of marketing intelligence is critical to ensuring interpretation and effective marketing planning.

Within the UK retail sector Tesco Clubcard is by far the largest retailer loyalty card, comprising 17 million shoppers (approximately 40 percent of UK households), followed by Sainsbury's Nectar Card (12 million) and Boots (ten million shoppers) (Ziliani and Bellini, 2004). Tesco Clubcard marketing intelligence, managed by dunnhumby, is available through a web portal called "The Shop." This comprises a set of analytical tools that firms can buy into to help build reports and gain insight into how their products are performing in all Tesco UK outlets (Humby et al., 2007). It is an expensive intelligence source but firms prepared to act on the information the shop provides can see the value and the return on investment (Humby et al., 2007). The power of retailer loyalty card marketing intelligence relates to its insights into specific consumer niches and their actual buying behaviors, how specific product categories are performing, and how specific suppliers are performing. This enables retailers and their suppliers to work out not just who is buying their products, but also helps to identify other products that each specific customer is likely to want (Cacciolatti et al., 2009). Building upon and synthesizing the literature presented, in the next section we develop a conceptual model, which interprets the relationship between relationship between small business MO and retailer loyalty card marketing intelligence, while also introducing integral elements such as EO.

\section{Conceptual development}

Literature has emphasized the informal marketing planning approach of small businesses driven by their owner-managers (O’Dwyer et al., 2009). Defining small business MO, their use of informally based networking with customers, suppliers and even competitors forms the basis of the generation, dissemination and response to 
marketing intelligence. However, in many markets where small businesses supply retailers, an understanding of competition and consumers is being defined by more formalized means of generating, disseminating and responding to marketing intelligence. Tesco Clubcard data are a representative example, disseminated through their subsidiary, dunnhumby, via the "Shop." Small businesses have limited exposure to this kind of formalized marketing intelligence in their daily routines, due to the lack of marketing expertise, time and resource available to them (Jocumsen, 2004). Also, small businesses typically take a short-term focus finding little relevance in longer-term marketing planning often due to a struggle to grow, or simply survive (Kirchoff, 1994; Doern, 2009). Which comes back to our consideration in this paper of the potential relationship between retailer loyalty card marketing intelligence and small business marketing planning.

A conceptual model is presented in Figure 1, which diagrammatically interprets how retailer loyalty card marketing intelligence can relate to small business MO. We also introduce the concept of an EO into the model. Recent work on small business MO has begun to consider the role of an EO as critical to understanding the relationship with innovation and performance outcomes. The model and propositions presented provide pertinent implications for owner-managers in their marketing planning approaches as well as research implications which we subsequently present.

Armario et al. (2008) state that MO facilitates the development of learning processes, as firm employees apply their knowledge to the solution of market problems. From this perspective, MO is considered an internal capability of the firm that is difficult to imitate (Day, 1994). It can also orient them toward the search for growth opportunities, while reducing opportunity response time (Kirca et al., 2005). Larger businesses have the resources to develop learning-based MO routines in a formalized and structured manner, which is beyond the means of most small businesses. For smaller businesses these learning processes relate to their unique nature (e.g. limited resource base, simple organizational structure, informal business processes, networking, owner-manager dominance) (Blankson and Omar, 2002; McCarton-Quinn and Carson, 2003; Moriarty et al., 2008), being based upon a more informal, unstructured and experiential context (e.g. intuitive awareness of markets) (Blankson et al., 2006). These learning routines could be viewed as patently unsuited to the formalized structure and presentation of retailer loyalty card marketing intelligence. However, while it may be logical to assume this a closer look at the literature provides a potentially new angle from which to view this from the perspective of small business exposure to retailer loyalty card marketing intelligence.

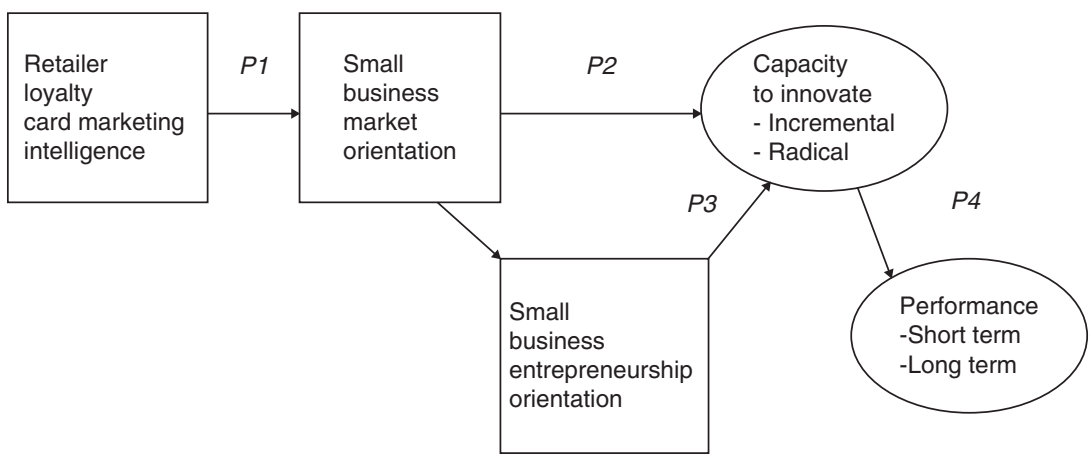

\section{Digital customer} loyalty data

523

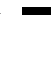


MIP

30,5

524
Corbett (2005) relates experiential learning in small businesses to an information acquisition and transformation experience. Significantly, MO is viewed as a transformational competency, requiring the transformation of marketing intelligence into marketing planning responses aimed at achieving customer satisfaction and competitive advantage (Armario et al., 2008). Pelham and Wilson (1996) and Pelham (2000), indicate that the typically low levels of formalization in small businesses' marketing planning will not necessarily reduce the innovative and flexible aspects of their ways of achieving this. Recent work by Simmons et al. (2011) suggests that an informal-formal synergy may exist in this regard.

In a study of small business web site optimization they found that those firms at leading edge were positively influenced by using cost-effective web tools such as web analytics, online surveys, community forums and database technology. These tools were used to facilitate more formalized and structured approaches to understanding online customers. Simmons et al. (2011) found that such tools complemented and supported online and offline the more informal type of marketing planning the small businesses studied would normally practice. They based this on small business competencies such as creativity, flexibility and intuitive judgment. Retailer loyalty card marketing intelligence represents a formalized approach to understanding customers which, building on Simmons et al. (2011), could be complemented and enhanced by small businesses in their unique and more informal style of marketing planning. Therefore, access to this intelligence could increase their MO levels by leveraging an informal/formal marketing planning synergy. From this we propose the following:

P1. Small business exposure to retailer loyalty card marketing intelligence will have a positive impact on their MO.

Baker and Sinkula (2009) reveal that a high level of MO will lead to market-driven small business behavior and incremental innovations. Incremental innovations represent ongoing improvements to existing product, process and service (Han et al., 1998; Slater and Narver, 1999). Small businesses are often constrained in developing innovations due to the need to step out from the industry norms. Becker (1982) states that any industry will exist within certain customs and practices, outside of which it is difficult to find acceptance. These established norms are so strong in most sectors that they will determine how business is done (Williamson, 1985; Camerer and Vepsalaien, 1988). In particular, small businesses are believed to conform to established industry norms in order to do business, primarily because they are small and cannot hope to step out from established practices (Fuller, 1994). Carson and Gilmore (2000) go as far as to state that most small businesses can only ever hope to attain some relatively marginal differentiation, and therefore must conform to the industry customs and practices in presenting this differentiation. However, retailer loyalty card marketing intelligence and its provision of precise customer insights could provide the confidence that small business owner-managers need to manage the risks, while proactively stepping outside industry norms to develop incremental innovations that are market based and relevant to customers. Therefore we propose the following:

P2. Small business exposure to retailer loyalty card data will have a positive impact on incremental innovations. 
An EO can facilitate the development of learning processes that allow a firm to adapt to their environment to exploit new opportunities, leading to new and often dynamic competitive spaces (Shane and Venkataraman, 2000). The relevant traits (innovativeness, risk tolerance and proactiveness) are often more associated with smaller as opposed to larger firms (Li et al., 2008; Baker and Sinkula, 2009). For small business owner-managers, these entrepreneurial traits can be encouraged and enhanced within the unique nature of their firms (e.g. limited resource base, simple organizational structure, informal business processes) (Schindehutte et al., 2008; Baker and Sinkula, 2009; Renko et al., 2009). Baker and Sinkula's (2009) results suggest that small business EO complements their MO by instilling an opportunistic culture that impacts the quality and quantity of their capacity to innovate. Small businesses, therefore, require an understanding of the need to balance a strong EO with a strong MO. Li et al. (2008) hypothesized that an appropriate alignment between MO and EO was critical to small business performance.

However, a major criticism of $\mathrm{EO}$ is that it creates the conditions radical innovations that can be in advance of market requirements, and therefore may be deemed a failure more often than a success (e.g. Hamel and Prahalad, 1994; Slater and Narver, 1995, 1999, 2000; Baker and Sinkula, 1999; Zahra, 2008). Noting the results of Baker and Sinkula (2009), we do not propose in this conceptualization that retailer loyalty card marketing intelligence will directly impact upon small business EO. However, we do posit that enhanced levels of $\mathrm{MO}$ through exposure to the marketing intelligence can provide the confidence that small business owner-managers need to manage the risks, while proactively stepping outside industry norms to develop radical innovations that are market-focussed and relevant to customers. We therefore propose the following:

P3. Enhanced MO through exposure to retailer loyalty card marketing intelligence will complement small business EO in developing market-focussed radical innovations.

Literature has indicated that higher levels of small business MO will result in a positive impact on small business performance (Pelham, 1997, 2000; Blankson and Cheng, 2005: Blankson et al., 2006; Armario et al., 2008; Baker and Sinkula, 2009). We qualify this with the contention that this will be short-term performance. Jaworski et al. (2000), make the point that $\mathrm{MO}$ can create differentiated competitive positions by managing the present through short-term market-driven actions and incremental innovations. Atuahene-Gima and Ko (2001), concurring with P2 and P3, found that firms with high levels of MO and EO, ME firms, were more successful in introducing incremental and radical innovations. Jaworski et al. (2000) and Kumar et al. (2000) state that exceptional organizations manage the present through short-term market-driven actions and incremental innovation. Simultaneously, or consecutively, they consider how to reshape markets by driving them over the longer term into new competitive spaces through radical innovation. Therefore we propose the following:

P4. Small businesses enhanced MO post-exposure to retailer loyalty card marketing intelligence and with high levels of EO can achieve exceptional short-term and long-term performance.

\section{Discussion}

We posit in this paper that a critical aspect of owner-managers' utilization of formalized marketing intelligence will be their insight (see e.g. Clarke et al., 2006).

\section{Digital customer loyalty data}

525 
MIP

30,5

526
Scholars, such as Mintzberg (1989) and Weick (1995), define intuition in the context of insight. Insight represents the seeing and understanding of the inner nature of things; facilitated by intuition. Thereby intuition is defined as "the immediate knowing of something without conscious use of reasoning" (Vaghely and Julien, 2010, p. 74). Small business owner-managers are praised for being flexible and intuitive in their planning approaches. Considering the findings of Simmons et al. (2011), the synergy facilitated by formalized retailer loyalty card marketing intelligence appears to reside in a potentially complementary relationship with informally based owner-manager insight and intuition underpinning marketing planning approaches. As Tesco Marketing Director Simon Uwins has commented, retailer loyalty card marketing intelligence can move firms from being intuitive to being more analytical, while also leveraging their intuition through the marketing intelligence to lead to better thinking, and the confidence to ask the right questions in their marketing planning process (see Humby et al., 2007, p. 107).

Central to this is the experiential knowledge of the owner-manager (Grant et al., 2001) and how, as an aspect of their MO, it could determine their use, or lack thereof, of formalized retailer loyalty card marketing intelligence. Corbett (2005) focussed on experiential learning within the process of opportunity identification and exploitation. In this context, Shane and Venkataraman (2000) indicate that small business ownermanagers "must possess prior knowledge and the cognitive properties" in order to be able to identify, develop and exploit opportunities. By considering the relationship between formalized retailer loyalty card marketing intelligence and informal ownermanager insight and intuition, the opportunity is also presented for owner-managers to reflect on and enhance their experiential learning in order to consider new more analytical approaches to their marketing planning that still retain and leverage their innate insights and intuition.

An important aspect of this is the role of an EO. Marketing planning in small businesses is implicitly associated with an entrepreneurial approach (Schindehutte et al., 2008). An EO can facilitate the development of learning processes that allow a firm to adapt to their environment to exploit new opportunities, leading to new and often dynamic competitive spaces (Shane and Venkataraman, 2000). Owner-manager experiential learning is based on an informal, unstructured context (encouraging a more intuitive awareness of markets). This is not easily matched to the formalized generation, dissemination and responsiveness to marketing intelligence underpinning larger business MO. However, it can be viewed as particularly relevant to the generative learning associated with EO that challenges existing market perceptions (e.g. Atuahene-Gima and Ko, 2001; Baker and Sinkula, 2009). It is the complementary alignment of an enhanced MO through retailer loyalty card marketing intelligence exposure with high levels of EO that can facilitate small business owner-managers in implementing marketing planning processes that proactively exploit market-based opportunities, while managing risks with more confidence borne from a more precise understanding of their markets. A particular feature of this complementary relationship is the increased potential for incremental and radical innovations that are in tune with market needs. This can form the basis of short-term and longer-term superior performance and may have significant implications on the success of small businesses in presenting new products in an informed, professional and confident manner to larger suppliers such as Tesco or other major retail multiples.

Therefore, when considering the potential of retailer loyalty card marketing intelligence, small business owner-managers need to also consider their level of MO 
and EO. MO studies have increasingly integrated an EO when considering performance implications (e.g. Atuahene-Gima and Ko, 2001; Gonzalez-Benito et al., 2009; Matsuno et al., 2002; Zahra, 2008). While this research has largely focussed on a general business context, the small business literature has been slow in following. However, recent research has indicated that EO may be critical in complementing MO in smaller businesses to boost performance (Li et al., 2008; Baker and Sinkula, 2009). For small business owner-managers it may be difficult to recognize, or admit, weaknesses in these orientations. However, without recognition, and more importantly rectification, owner-managers will be constrained in leveraging retailer loyalty card marketing intelligence. Changing to a marketing-oriented mindset will be difficult requiring culture change - and will not happen overnight. However, small business owner-managers will have to at least recognize its importance in this respect. While small businesses are considered to be inherently entrepreneurial, they may do well to reflect on their proactiveness, risk-taking attitudes and innovativeness in product development and business processes.

Developments in these areas can also contribute to the further study of retailer loyalty card marketing intelligence and its particular relevance to marketing planning. To date research has largely focussed on the value of loyalty cards for the consumer and for multiple retailers (Ziliani and Bellini, 2004). However, actual understanding of retailer loyalty card marketing intelligence and the relationship with marketing planning is still not clear (Cortiñas et al., 2008). Also, a more specific consideration of small businesses in the literature has not been developed to any extent. Small businesses are simply viewed as being too small, lacking the resources, time and expertise as well as the funds to access and make sense of complex, formalized marketing intelligence. The role of loyalty card marketing intelligence extends the scope and relevance of its potential use as a marketing planning tool for small businesses in this respect. The complementary relationship we put forward in this paper holds much promise in terms of applied, theoretical and research implications going forward.

\section{Conclusions and research implications}

This paper provides a conceptual basis for extending an understanding of the potential in the relationship between retailer loyalty card marketing intelligence and small business marketing planning. Small business owner-managers could benefit from such formalized marketing intelligence, while requiring the experiential knowledge and capabilities needed to leverage it in their marketing planning approaches. This also produces potentially significant policy implications. Government bodies charged with supporting and growing small businesses and their economic contribution, need to provide the access, initial training and interpretation skills to utilize such formalized marketing intelligence in their marketing planning. Policy makers may also consider other types of formalized marketing intelligence beyond retailer loyalty cards, to aid small business development and economic contribution.

It should be noted that to conduct further research to address the propositions presented and to extend our understanding of this important area of marketing planning, researchers will need to secure access for small businesses to retailer loyalty card marketing intelligence. Government agencies are increasingly keen to work with universities and research bodies to make retailer loyalty card marketing intelligence available to small firms and to provide initial interpretation. An example is the University of Kent's Business School. In April 2005 a joint venture was established

\section{Digital customer loyalty data}

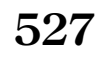


MIP

30,5

528

between their Centre for Value Chain Research and dunnhumby. This partnership provides a mechanism for small firms to access shopper insight from the largest consumer database in the UK derived from Tesco Clubcard data.

Due to the lack of research in this area an exploratory approach for future research is required initially. Typically, the marketing/MO fields are dominated by quantitative studies mostly consisting of large firms (Tregear, 2003) using very structured instruments to statistically rationalize results (Kohli and Jaworski, 1990; Narver and Slater, 1990; Greenley, 1995). Qualitative case study-based research is particularly suited to disaggregating the MO and $\mathrm{EO}$ concepts, to probe which components are relevant to leveraging retailer loyalty card marketing intelligence in marketing planning approaches. Specifically, a case study-based approach could involve small businesses being provided with retailer loyalty card marketing intelligence, with initial support provided for its interpretation at the level of individual businesses. Longitudinal cases could involve researcher engagement with small firms through workshops on a sectoral basis where the marketing intelligence is delivered and interpreted. Researchers would utilize the workshop engagements as a basis for conducting in-depth interviews and observational study. The same firms could be invited to a second workshop at a later date. Due to the nature of the research and the role of retailer loyalty card marketing intelligence, in-depth interviews need to be conducted a priori in the first instance; that is exploring the nature of MO before the introduction of the marketing intelligence to small business owner-managers. Interviews then need to be conducted a posteriori; that is probing after the introduction of retailer loyalty card marketing intelligence. The timing of this a posteriori, should ensure that owner-managers have had time to digest and react to the insights derived from the marketing intelligence, and therefore that the intelligence will have potentially caused positive changes in their marketing planning approaches. Future research in this area will serve to increase our understanding of this and facilitate original insight into an emerging and highly topical area of study.

\section{References}

Alpkan, L., Yilmaz, C. and Kaya, N. (2007), "Market orientation and planning flexibility in SMEs: performance implications and an empirical investigation", International Small Business Journal, Vol. 25 No. 2, pp. 152-72.

Anstead, J., Samuel, J. and Crofton, A. (2008), “dunnhumby - a retailer's secret weapon", Citigroup Global Market, Vol. 60 No. 60, pp. 1-25.

Argyris, C. (1977), "Double loop learning in organizations", Harvard Business Review, Vol. 55 No. 5 , pp. 115-25.

Armario, J.M., Ruiz, D.M. and Armario, E.M. (2008), "Market orientation and internationalisation in small and medium-sized enterprises", Journal of Small Business Management, Vol. 46 No. 4, pp. 485-512.

Atuahene-Gima, K. and Ko, A. (2001), "An empirical investigation of the effect of market orientation and entrepreneurship orientation alignment on product innovation", Organization Science, Vol. 12 No. 1, pp. 54-74.

Avlonitis, G.J. and Gounaris, S.P. (1997), "Marketing orientation and company performance", Industrial Marketing Management, Vol. 26, pp. 349-60.

Baker, W.E. and Sinkula, J.M. (1999), "The synergistic effect of market orientation and learning orientation on organizational performance", Journal of the Academy of Marketing Science, Vol. 27 No. 4, pp. 411-27. 
Baker, W.E. and Sinkula, J.M. (2009), "The complementary effects of market orientation and entrepreneurial orientation on profitability in small businesses", Journal of Small Business Management, Vol. 47 No. 4, pp. 443-64.

Becker, H.S. (1982), Art World, University of California Press, Berkeley, CA.

Bhide, A. (1994), "How entrepreneurs craft strategies that work", Harvard Business Review, Vol. 72 No. 2, pp. 150-61.

Blankson, C. and Cheng, J.M.S. (2005), "Have small businesses adopted the market orientation concept? The case of small businesses in Michigan", Journal of Business and Industrial Marketing, Vol. 20 No. 6, pp. 317-30.

Blankson, C. and Omar, O.E. (2002), "Marketing practices of African and Caribbean small businesses in London, UK", Qualitative Market Research: An International Journal, Vol. 5 No. 2, pp. 123-34.

Blankson, C. and Stokes, D. (2002), "Marketing practices in the UK small business sector", Market Intelligence and Planning, Vol. 20 No. 1, pp. 49-61.

Blankson, C., Motwani, J.G. and Levenburg, N.M. (2006), "Understanding the patterns of market orientation among small businesses", Market Intelligence and Planning, Vol. 24 No. 6, pp. 572-90.

Cacciolatti, L., Donnelly, C., Fearne, A., Ihua, U., Yawson, D., Armstrong, G. and Simmons, G. (2009), "Use of supermarket panel data amongst small and medium sized business in the food industry", Academy of Marketing Conference, Leeds Metropolitan University, Leeds, July 7-9.

Cambra-Fierro, J., Florin, J., Perez, L. and Whitelock, J. (2011), "Inter-firm market orientation as antecedent of knowledge transfer, innovation and value creation in networks", Management Decision, Vol. 49 No. 3, pp. 444-67.

Camerer, C. and Vepsalaien, A. (1988), "The economic efficiency of corporate culture”, Strategic Management Journal, Vol. 9, pp. 115-26.

Carson, D. and Gilmore, A. (2000), "Marketing at the interface: not 'what' but 'how', Journal of Marketing Theory and Practice, Vol. 8 No. 2, pp. 1-7.

Chandy, R., Prabhu, J. and Antia, K. (2003), "What will the future bring? Technology expectations, dominance, and radical product innovation", Journal of Marketing, Vol. 66 (July), pp. 1-18.

Clarke, J., Thorpe, R., Anderson, C. and Gold, J. (2006), "It's all action, it's all learning: action learning in SMEs", Journal of European Industrial Training, Vol. 30 No. 6, pp. 441-55.

Corbett, A.C. (2005), "Experiential learning within the process of opportunity identification and exploitation", Entrepreneurship Theory and Practice, Vol. 29 No. 4, pp. 473-92.

Cortiñas, M., Elorz, M. and Múgica, J.M. (2008), “The use of loyalty-cards databases: differences in regular price and discount sensitivity in the brand choice decision between card and non-card holders", Journal of Retailing and Consumer Services, Vol. 15 No. 1, pp. 52-62.

Day, G.S. (1994), “The capabilities of market-driven organisations”, Journal of Marketing, Vol. 58 No. 4, pp. 37-61.

Deshpande, R. and Farley, J.U. (1998), "Measuring market orientation: generalisation and synthesis", Journal of Market-focused Management, Vol. 2 No. 3, pp. 23-37.

Doern, R. (2009), "Investigating barriers to SME growth and development in transition environments", International Small Business Journal, Vol. 27 No. 3, pp. 275-305.

Drucker, P.F. (1954), The Practice of Management, Heron Books, London.

Dunn, E. (2006), It's Marketing Jim, But Not as We Know It, 1st ed., dunnhumby, London.

Everett, C. (2009), "Loyalty cards: the risks and rewards", Infosecurity, Vol. 6 No. 5, pp. 17-9. 
MIP

30,5

530
Fuller, P.B. (1994), "Assessing marketing in small and medium-sized enterprises”, European Journal of Marketing, Vol. 28 No. 12, pp. 34-49.

Gatignon, H. and Xuereb, J. (1997), "Strategic orientation of the firm and new product performance", Journal of Marketing Research, Vol. 34 No. 1, pp. 77-90.

Gilmore, A., Carson, D. and Grant, K. (2001), "SME marketing in practice”, Marketing Intelligence and Planning, Vol. 19 No. 1, pp. 6-11.

Gilmore, A., Carson, D., Grant, K., O’Donnell, A., Laney, R. and Pickett, B. (2006), "Networking in SMEs: findings from Australia and Ireland", Irish Marketing Review, Vol. 18 Nos 1/2, pp. 21-8.

Gonzalez-Benito, O., Gonzalez-Benito, J. and Munoz-Gallego, P.A. (2009), "Role of entrepreneurship and market orientation in firms' success", European Journal of Marketing, Vol. 43 Nos 3/4, pp. 500-22.

Grant, K., Gilmore, A., Carson, D., Laney, R. and Pickett, B. (2001), "Experiential' research methodology: an integrated academic practitioner 'team' approach”, Qualitative Market Research, Vol. 4 No. 2, pp. 66-75.

Greenley, G.E. (1995), "Forms of market orientation in UK companies", Journal of Management Studies, Vol. 32 No. 1, pp. 47-66.

Hamel, G. and Prahalad, C.K. (1994), Competing for the Future, Harvard Business School Press, Cambridge, MA.

Han, J.K., Kim, N. and Srivastava, R.K. (1998), "Market orientation and organizational performance: is innovation a missing link?", Journal of Marketing, Vol. 62 No. 10, pp. 76-89.

Harris, L.C. (2002), "Measuring market orientation: exploring a market orientated approach", Journal of Market-focused Management, Vol. 5 No. 3, pp. 239-70.

Harris, L.C. and Watkins, P. (1998), "The impediments to developing a market orientation: an exploratory study of small UK hotels", International Journal of Contemporary Hospitality Management, Vol. 10 No. 6, pp. 221-6.

Homburg, C. and Pflesser, C. (2000), "A multiple-layer model of market-oriented organisational culture: measurement issues and performance outcomes", Journal of Marketing Research, Vol. 37 No. 4, pp. 449-62.

Hult, G.T., Snow, C.C. and Kandemir, D. (2003), "The role of entrepreneurship in building cultural competitiveness in different organizational types", Journal of Management, Vol. 29 No. 3, pp. 401-26.

Hunt, S.D. and Morgan, R.M. (1995), "The comparative advantage theory of competition”, Journal of Marketing, Vol. 59 No. 2, pp. 1-15.

Humby, C., Hunt, T. and Phillips, T. (Eds) (2007), Scoring Points: How Tesco Continues to Win Customer Loyalty, 2nd ed., Kogan Page, London.

Jaworski, B.J. and Kohli, A. (1993), "Market orientation: antecedents and consequences”, Journal of Marketing, Vol. 57 No. 1, pp. 53-70.

Jaworski, B.J. and Kohli, A.K. (1996), "Market orientation: review, refinement and roadmap", Journal of Market-focused Management, Vol. 1 No. 2, pp. 119-35.

Jaworski, B., Kohli, A.J. and Sahay, A. (2000), "Market-driven versus driving markets", Journal of the Academy of Marketing Science, Vol. 28 No. 1, pp. 45-54.

Jocumsen, G. (2004), "How do small business managers make strategic marketing decisions? A model of process", European Journal of Marketing, Vol. 38 Nos 5/6, pp. 659-74.

Jones, O., Macpherson, A., Thorpe, R. and Ghecham, A. (2007), "The evolution of business knowledge in SMEs: conceptualising strategic space", Strategic Change, Vol. 16 No. 6, pp. 281-94. 
Jones, R. and Rowley, J. (2011), "Entrepreneurial marketing in small businesses: a conceptual exploration”, International Small Business Journal, Vol. 29 No. 1, pp. 25-36.

Kara, A., Spillan, J.E. and DeShields, O.W. Jr (2005), "The effect of a market orientation on business performance: a study of small-sized service retailers using the Makor scale", Journal of Small Business Management, Vol. 43 No. 2, pp. 105-18.

Kerin, R.A. (1996), "In pursuit of an ideal: the editorial and literary history of the Journal of Marketing", Journal of Marketing, Vol. 60 No. 1, pp. 1-13.

Kirchoff, B.A. (1994), Entrepreneurship and Dynamic Capitalism: The Economics of a Business Firm Formation and Growth, Praegar, Westport, CT.

Kohli, A.K. and Jaworski, B.J. (1990), "Market orientation: the construct, research propositions, and managerial implication", Journal of Marketing, Vol. 54 No. 2, pp. 1-18.

Kumar, N., Sheer, L. and Kotler, P. (2000), "From market driven to market driving”, European Management Journal, Vol. 18 No. 2, pp. 129-42.

Kirca, A.H., Jayachandran, S. and Bearden, W.O. (2005), "Market orientation: a meta-analytic review and assessment of its antecedents and impact on performance", Journal of Marketing, Vol. 69 No. 2, pp. 24-41.

Lafferty, B.A. and Hult, G.T.M. (2001), "A synthesis of contemporary market orientation perspectives”, European Journal of Marketing, Vol. 35 Nos 1/2, pp. 92-109.

Lewis, K., Massey, C. and Harris, C. (2007), "Learning by doing: 6 dimensions of complexity in researching SMEs", Qualitative Research in Accounting and Management, Vol. 4 No. 2, pp. 151-63.

Li, Y., Zhao, Y., Tan, J. and Liu, Y. (2008), "Moderating effects of entrepreneurial orientation on market orientation-performance linkage: evidence from Chinese small firms", Journal of Small Business Management, Vol. 46 No. 1, pp. 113-33.

Liberman-Yaconi, L., Hooper, T. and Hutchings, K. (2010), “Toward a model of understanding strategic decision-making in micro-firms: exploring the Australian information technology sector", Journal of Small Business Management, Vol. 48 No. 1, pp. 70-95.

McCarthy, B. (2003), "Strategy is personality-driven, strategy is crisis-driven: insights from entrepreneurial firms", Management Decision, Vol. 41 No. 4, pp. 327-39.

McCarton-Quinn, D. and Carson, D. (2003), "Issues which impact upon business markets in the small firm”, Small Business Economics, Vol. 21 No. 2, pp. 210-3.

Martin, J.H., Martin, B.A. and Minnillo, P.R. (2009), "Implementing a market orientation in small manufacturing firms: from cognitive model to action", Journal of Small Business Management, Vol. 47 No. 1, pp. 92-115.

Matsuno, K., Mentzer, J.T. and Ozsomer, A. (2002), "The effects of entrepreneurial proclivity and market orientation on business performance", Journal of Marketing, Vol. 66 No. 3, pp. 18-32.

Mauri, C. (2003), "Card loyalty. A new emerging issue in grocery retailing”, Journal of Retailing and Consumer Services, Vol. 10 No. 1, pp. 13-25.

Mazzarol, T., Reboud, S. and Soutar, G.N. (2009), "Strategic planning in growth oriented small firms", International Journal of Entrepreneurial Behaviour \& Research, Vol. 15 No. 4, pp. 320-45.

Menguc, B. and Auh, S. (2006), "Creating a firm-level dynamic capability through capitalizing on market orientation and innovativeness", Journal of the Academy of Marketing Science, Vol. 34 No. 1, pp. 63-73.

Mintzberg, H. (1989), Mintzberg on Management, Free Press, New York, NY.

Miller, D. and Toulouse, J.M. (1986), "Chief executive personality and corporate strategy and structure in small firms", Management Science, Vol. 32 No. 11, pp. 1389-409.

\section{Digital customer} loyalty data

531 
MIP

30,5

532
Moriarty, J., Jones, R., Rowley, J. and Kupiec-Teahan, B. (2008), "Marketing in small hotels: a qualitative study", Marketing, Intelligence and Planning, Vol. 26 No. 3, pp. 293-315.

Narver, J.C. and Slater, S.F. (1990), "The effect of a market orientation on business profitability", Journal of Marketing, Vol. 54 No. 4, pp. 20-35.

Narver, J.C., Slater, S.F. and MacLachlan, D.L. (2004), "Responsiveness and proactive market orientation and new-product success", Journal of Product Innovation Management, Vol. 21 No. 5, pp. 334-47.

Nieto, M.J. and Santamaria, L. (2010), "Technological collaboration: bridging the innovation gap between small and large firms”, Journal of Small Business Management, Vol. 48 No. 1, pp. 44-69.

O’Dwyer, M., Gilmore, A. and Carson, D. (2009), "Innovative marketing in SMEs", European Journal of Marketing, Vol. 43 Nos 1/2, pp. 46-61.

Panigyrakis, G.G. and Theodoridis, P.K. (2007), "Market orientation and performance: an empirical investigation on the retail industry in Greece", Journal of Retailing and Consumer Service, Vol. 14 No. 2, pp. 137-49.

Pelham, A.M. (1997), "Market orientation and performance: the moderating effects of product and customer differentiation", Journal of Business \& Industrial Marketing, Vol. 12 No. 5, pp. 276-96.

Pelham, A.M. (2000), "Market orientation and other potential influences on performance in small and medium-sized manufacturing firms", Journal of Small Business Management, Vol. 38 No. 1, pp. 48-67.

Pelham, A.M. and Wilson, D.T. (1996), "Longitudinal study of the impact of market structure, firm structure, strategy, and market orientation culture on dimensions of small firm performance", Journal of the Academy of Marketing Science, Vol. 24 No. 1, pp. 27-43.

Perks, K. (2006), "Influences on strategic management styles among fast growing medium-sized firms in France and Germany", Strategic Change, Vol. 15 No. 3, pp. 153-64.

Renko, M., Carsrud, A. and Brannback, M. (2009), "The effect of a market orientation, entrepreneurial orientation, and technological capability on innovativeness: a study of young biotechnology ventures in the Unites States and in Scandinavia", Journal of Small Business Management, Vol. 47 No. 3, pp. 331-69.

Schindehutte, M., Morris, M.H. and Kocak, A. (2008), "Understanding market-driving behavior: the role of entrepreneurship”, Journal of Small Business Management, Vol. 46 No. 1, pp. 4-27.

Senge, P. (1990), The Fifth Discipline, Currency Doubleday, New York, NY.

Shane, S. and Venkataraman, S. (2000), "The promise of entrepreneurship as a field of research", Academy of Management Review, Vol. 25 No. 1, pp. 217-26.

Shapiro, B. P. (1988), "What the hell is market orientated?", Harvard business review, Vol. 1 No 1, pp. 119-125.

Simmons, G., Armstrong, G.A. and Durkin, M.G. (2011), "An exploration of small business website optimization: enablers, influencers and an assessment approach", International Small Business Journal, Vol. 29 No. 5, pp. 534-61.

Simmons, G., Armstrong, G., Fearne, A. and Robinson, R. (2008), "Utilisation of customer insight by SME food businesses", 31st Institute for Small Business and Entrepreneurship Conference, Belfast, Northern Ireland, November 5-7, pp. 1-10.

Sinkula, J.M. (1994), "Market information progressing and organizational learning", Journal of Marketing, Vol. 58 No. 1, pp. 35-45.

Sinkula, J.M., Baker, W. and Noordwier, T.G. (1997), “A framework for market-based organizational learning: linking values, knowledge and behavior", Journal of the Academy of Marketing Science, Vol. 25 No. 4, pp. 305-18. 
Slater, S.F. and Narver, J.C. (1994), "Market orientation, customer value, and superior performance", Business Horizons, Vol. 37 No. 2, pp. 22-8.

Slater, S.F. and Narver, J.C. (1995), "Market orientation and the learning organization", Journal of Marketing, Vol. 59 No. 3, pp. 63-74.

Slater, S.F. and Narver, J.C. (1999), "Market-oriented is more than being customer-led", Strategic Management Journal, Vol. 20 No. 12, pp. 1165-8.

Slater, S.F. and Narver, J.C. (2000), "The positive effect of a market orientation on business profitability: a balanced replication”, Journal of Business Research, Vol. 48 No. 1, pp. 69-73.

533

Smith, A. and Sparks, L. (2009), “It's nice to get a wee treat if you've had a bad week': consumer motivations in retail loyalty scheme points redemption”, Journal of Business Research, Vol. 62 No. 5, pp. 542-7.

Sorensen, H.E. (2009), "Why competitors matter for market orientation", European Journal of Marketing, Vol. 43 Nos 5/6, pp. 735-61.

Stokes, D. (2000), "Putting entrepreneurship into marketing: the processes of entrepreneurial marketing", Journal of Research in Marketing \& Entrepreneurship, Vol. 2 No. 1, pp. 1-16.

Tregear, A. (2003), "Market orientation and the craftsperson", European Journal of Marketing, Vol. 37 Nos 11/12, pp. 1621-35.

Turner, J.J. and Wilson, K. (2006), "Grocery loyalty: Tesco Clubcard and its impact on loyalty", British Food Journal, Vol. 108 No. 11, pp. 258-64.

Vaghely, I.P. and Julien, P. (2010), “Are opportunities recognized or constructed?: an information perspective on entrepreneurial opportunity identification", Journal of Business Venturing, Vol. 25 No. 1, pp. 73-86.

Weick, K. (Ed.) (1995), Sensemaking in Organisations, Sage, Thousand Oaks, CA.

Welsh, J.A. and White, J.F. (1981), "A small business is not a little big business", Harvard Business Review, Vol. 59 No. 4, pp. 18-32.

Williamson, O.E. (1985), Markets and Hierarchies: Analysis and Antitrust Implications, The Free Press, New York, NY.

Wilson, N.C. and Stokes, D. (2004), "Laments and serenades: relationship marketing and legitimation strategies for the cultural entrepreneur", Qualitative Market Research: An International Journal, Vol. 7 No. 3, pp. 218-27.

Wright, C. and Sparks, L. (1999), "Loyalty saturation in retailing: exploring the end of retail loyalty cards", International Journal of Retail and Distribution Management, Vol. 27 No. 10 , pp. 429-39.

Zahra, S.A. (2008), "Being entrepreneurial and market-driven: implications for company performance", Journal of Strategy and Management, Vol. 1 No. 2, pp. 125-42.

Ziliani, C. and Bellini, S. (2004), "From loyalty cards to micro-marketing strategies: where is Europe's retail industry heading?", Journal of Targeting, Measurement and Analysis for Marketing, Vol. 12 No. 3, pp. 281-9.

Zontanos, G. and Anderson, A.R. (2004), "Relationships, marketing and small business: an exploration of links in theory and practice", Qualitative Market Research: An International Journal, Vol. 7 No. 3, pp. 228-36.

\section{Further reading}

Hult, T.M.G. and Ketchen, D.J. (2001), "Does market orientation matter: a test of the relationship between positional advantage and performance", Strategic Management Journal, Vol. 22 No. 9, pp. 899-906.

Ziliani, C. (2006), "Target promotions: how to measure and improve promotional effectiveness through individual customer information", Journal of Targeting, Measurement and Analysis for Marketing, Vol. 14 No. 3, pp. 249-59. 
MIP

30,5

534

\section{About the authors}

Christina Donnelly lectures in Marketing at the National University of Ireland Maynooth. Her research interests are in marketing intelligence databases and small business marketing. She spearheaded a market intelligence project from 2008-2011 funded by the Department of Agriculture and Rural Development in Northern Ireland (DARD), exploring the relationship between dunnhumby marketing intelligence and small agri-food business market orientation. Christina Donnelly is the corresponding author and can be contacted at: cd233@kent.ac.uk

Geoff Simmons lectures in Marketing at the Ulster Business School, University of Ulster. His research interests are in marketing strategy research focused on technology innovations at the level of applications such as web sites, electronic databases (e.g. dunnhumby) and social media or at the level of technologically innovative sectors. He is actively involved in developing the research impact of the dunnhumby research project, at both the Ulster Business School and Kent Business School.

Gillian Armstrong is Head of Department of Accounting at the Ulster Business School, University of Ulster. Her research interests are in food marketing and consumer behaviour. She leads the dunnhumby research project at the Ulster Business School.

Andrew Fearne is Professor of Food Marketing and Supply Chain Management and Director of the Centre for Value Chain Research at Kent Business School, University of Kent. He leads a team of researchers based at the Kent Business School who are focused on dunnhumby marketing intelligence and its role in the UK agri-food industry.

To purchase reprints of this article please e-mail: reprints@emeraldinsight.com Or visit our web site for further details: www.emeraldinsight.com/reprints 